\title{
The Effect of Plasma Nitriding Parameters on the Thickness of Nitrided Layers
}

Ondrej Pilch, Frantisek Snahnican, Vojtech Hruby, Zbynek Studeny

Department of Mechanical Engineering, Faculty of Military Technology, University of Defence. Kounicova 65, 66210 Brno. Czech Republic. E-mail: ondrej.pilch@unob.cz, frantisek.snahnican@unob.cz, vojtech.hruby@unob.cz, zbynek.studeny@unob.cz

This paper is aimed at chemical-heat treatment of a selected material. The plasma nitriding layers were applied on the 41CrAIMo7-10 steel. The influence of plasma nitriding parameters on the thickness and microhardness of nitrided layers were investigated. Plasma nitriding was performed at $500^{\circ} \mathrm{C}$ with a mixture atmosphere of $\mathrm{H}_{2}$ and $\mathrm{N}_{2}$ in the plasma nitriding equipment. The pressure of plasma nitriding process was determined to be 280 Pa. The period of the plasma nitriding process was changeable from 5 to 30 hours. The microstructure and mechanical properties of the nitrided layers were studied by using GDOES spectrometry, optical microscopy, and hardness testing. The depths of the plasma nitriding layers were also estimated using cross-sectional microhardness profiles. Microhardness and surface hardness of mentioned samples were significantly increased. The measurements have shown that the period of plasma nitriding process has a significant influence on the depth of nitriding.

Keywords: Plasma Nitriding, Microhardnes, Nitriding Period, Nitrided Layer,

\section{Acknowledgements}

The paper was prepared with the support of the Project "Promoting Research, Science and Innovation in the Field of Engineering" of the Department of Mechanical Engineering, University of Defence.

\section{References}

[1] HRUBÝ, V., POKORNÝ, Z., LIPTÁK, P. (2013). Plasma nitriding of cavities. Rzeszów, Poland: RSdruk, Podgórska 4, 35-082 Rzeszów, 2013, 162 p. ISBN 978-83-63666-93-4.

[2] STUDENÝ, Z. (2015). Analysis of the influence of initiating inclusions on fatigue life in plasma nitrided steels. Manufacturing Technology, 2015, vol. 15, no. 1, p. 99-105. ISSN 1213-2489.

[3] HRUBÝ, V. (1991). Povrchové vrstvy ocelí a jejich příprava iontovou nitridací, Brno.

[4] RIE, K.T. (1999). Recent advances in plasma diffusion processes. ISSN.

[5] POKORNÝ, Z., KADLEC, J., HRUBÝ, V., et all. (2011). Hardness of plasma nitrided layers created at different conditions. Chemické listy, vol. 2011, no. 105, p. 717-720. ISSN 1213-7103.

[6] EN ISO 6507-1 Metallic materials - Vickers hardness test - Part 1: Test method. 1998

[7] STN EN ISO 14577-1: Metallic materials Instrumented indentation test for hardness and materials parameters Part 1: Test method

[8] PAYling, R., JONES, D., BENGTSON, A. (1997). Glow Discharge Optical Emission Sepctometry. England: John Wiley \& Sons Ltd. ISBN 0-471-96683-5

[9] HRUBÝ, V., POKORNÝ, Z., BARBORÁK, O. (2012). Characteristics of plasma nitrided layers in deep holes. KOVOVE MATERIALY-METALLIC MATERIALS, 2012, vol. 3, no. 50, p. 209-212. ISSN 0023-432X.

[10] KADLEC, J. (2008). Metodika hodnocení chemickeho složení a vlastností povlaků $\mathrm{FeFe}_{2} \mathrm{O}_{4}$, 18 s. Univerzita obrany, Brno ISBN: 978-7231-474-4

[11] DIN 50190-4:1999, Hardness depth of heat-treated parts - Part 4: Determination of the diffusion hardening depth and the diffusion depth

[12] DOBROCKY, D., KUSMIC, D. (2015). The Effect of Plasma Nitriding Process on the Change of Dynamic Parameters of Steel DIN 1654/4. Manufacturing Technology, vol. 15, no. 1, p. 14-20. ISSN 1213-2489.

[13] KUSMIC, D., DOBROCKY, D. (2015). Corrosion Resistance of Plasma Nitrided Structural Steels. Manufacturing Technology, vol. 15, no. 1, p. 64-69. ISSN 1213-2489. 